\title{
A Method for Isolation of Protoplasts from Dermatophytes
}

\author{
By T. SRIKANTHA AND G. RAMANANDA RAO* \\ Microbiology and Cell Biology Laboratory, Indian Institute of Science, Bangalore 560 012, India
}

(Received 7 November 1983; revised 13 December 1983)

A method has been developed to isolate protoplasts from dermatophytes using Novozym 234. A simple technique of flotation in $\mathrm{MgSO}_{4}$ has been adapted to separate protoplasts from incubation mixture. Electron microscopic studies confirmed the absence of cell wall material on these protoplasts. The recovery of DNA from protoplasts was higher than from mycelia.

\section{INTRODUCTION}

Lower eukaryotes like dermatophytes are known to contain less DNA per cell than do higher eukaryotes. In addition, they have a thick rigid cell wall surrounding the cell membrane, which makes them refractory to gentle methods of lysis. An attempt to demonstrate the presence of histones in Microsporum gypseum was unsuccessful due to poor yields of DNA (Leighton et al., 1971). Our initial efforts to obtain DNA from Microsporum canis in sufficient quantities by the method of Dill \& Stock (1974) also yielded low recoveries. Subsequently, we developed a simple and efficient method (unpublished) for the isolation of nuclear DNA from mycelium of $M$. canis, but the yields were not adequate to permit extensive characterization. Though sexuality has been well recognized in most of the dermatophytes (Hasegawa \& Usui, 1975), progress in genetic analysis is greatly hindered by difficulties encountered in the isolation of protoplasts for somatic fusion. The present report describes a novel method of preparing protoplasts from several dermatophytes.

\section{METHODS}

Cultural conditions. Ten-day-old macroconidia of various dermatophytes (see Table 1) grown on Sabouraud's agar slants were routinely used as inoculum. For primary culture in liquid medium [ $200 \mathrm{ml}$ Sabouraud's medium containing $2 \%(\mathrm{w} / \mathrm{v})$ glucose, $1 \%(\mathrm{w} / \mathrm{v})$ Bacto peptone and $0.004 \%$ each of chloramphenicol and cycloheximide], cultures were incubated for $24 \mathrm{~h}$ at $30^{\circ} \mathrm{C}$ on a gyratory shaker. Primary cultures were used to inoculate $200 \mathrm{ml}$ volumes of fresh medium at a ratio of $1: 20$. After incubation for $48 \mathrm{~h}$ as described above, this secondary culture was used in the isolation of protoplasts. Mycelia were most sensitive to Novozym 234 at around $48 \mathrm{~h}$ of culture. However, at this stage mycelia begin to produce extracellular slime. To remove the slime, mycelia were harvested by filtration through cheesecloth and washed with double-distilled water until free of slimy substance.

Preparation of protoplasts. Mycelia from $48 \mathrm{~h}$ cultures were extensively washed and suspended $\left(100 \mathrm{mg} \mathrm{ml}^{-1}\right)$ in $10 \mathrm{~mm}$-citrate/phosphate buffer ( $\mathrm{pH} \mathrm{5.2)} \mathrm{containing} 0.5 \mathrm{M}-\mathrm{MgSO}_{4}, 10 \mathrm{~mm}-\beta$-mercaptoethylamine and $5 \mathrm{mg}$ Novozym $234 \mathrm{ml}^{-1}$ (a gift from Novo Industri, A/S. Novo Alle, DK-2880 Bagsvaerd, Denmark). Samples (20 ml) in $50 \mathrm{ml}$ capacity culture tubes were incubated in a gyratory shaker $\left(150-200\right.$ r.p.m.) at $30^{\circ} \mathrm{C}$ for $9-10 \mathrm{~h}$, at which time protoplasts developed maximum vacuolation. Suspensions were then centrifuged at $650 \mathrm{~g}$ for $2 \mathrm{~min}$ in a HB-4 rotor in a Sorvall RC-5B centrifuge to separate vacuolated protoplasts from non-vacuolated protoplasts, spheroplasts and mycelia. The floating protoplast fraction was recovered carefully with a Pasteur pipette and was mixed with two volumes of $0.5 \mathrm{M}-\mathrm{KCl}$. It was then centrifuged at $1040 \mathrm{~g}$ for $5 \mathrm{~min}$ to pellet the protoplasts. The pellet was washed twice with $0.5 \mathrm{M}-\mathrm{KCl}$ and stored routinely in $0.5 \mathrm{M}-\mathrm{KCl}$ at $4{ }^{\circ} \mathrm{C}$ for further study. The number of protoplasts per sample was counted using a haemocytometer.

Extraction and estimation of DNA. DNA was extracted from $1 \mathrm{~g}$ protoplasts by suspending them in lysis buffer [0.15 $\mathrm{M}-\mathrm{NaCl}, 0.1 \mathrm{M}$-EDTA and $2 \%(\mathrm{w} / \mathrm{v}) \mathrm{SDS}, \mathrm{pH} 7 \cdot 6]$ and heating at $60^{\circ} \mathrm{C}$ for $10 \mathrm{~min}$. After cooling the sample to room temperature, solid sodium perchlorate was added to a concentration of $1 \mathrm{M}$ and the mixture was shaken for $30 \mathrm{~min}$ with one volume of chloroform/isoamyl alcohol $(24: 1, \mathrm{v} / \mathrm{v})$, followed by centrifuging at $4000 \mathrm{~g}$ for $10 \mathrm{~min}$. The aqueous phase containing the DNA was re-extracted with chloroform/isoamyl alcohol. Pronase 
$\left(1.5 \mathrm{mg} \mathrm{ml}^{-1}\right)$ was added to the aqueous phase and incubated at $45^{\circ} \mathrm{C}$ for $12 \mathrm{~h}$. After cooling to room temperature, DNA was precipitated with two volumes of ethanol $(95 \%, \mathrm{v} / \mathrm{v})$ and dried. It was dissolved in 10-fold diluted SSC $(15 \mathrm{mM}-\mathrm{NaCl}, 1.5 \mathrm{~mm}$-trisodium citrate, $\mathrm{pH} 7.0$ ) and brought to $0.15 \mathrm{M}$ with respect to $\mathrm{NaCl}$ and $0.015 \mathrm{M}$ with respect to trisodium citrate. Pancreatic RNAase and RNAase T1 were added to final concentrations of $50 \mu \mathrm{g} \mathrm{ml}^{-1}$ and 10 units $\mathrm{ml}^{-1}$, respectively and incubated for $30 \mathrm{~min}$ at $37^{\circ} \mathrm{C}$. $\mathrm{NaCl}$ was added to concentrations of $1 \mathrm{M}$ and DNA was re-precipitated with ethanol $(95 \%, \mathrm{v} / \mathrm{v})$ and estimated by the method of Giles \& Myers (1965). For comparison, mycelium grown for $72 \mathrm{~h}$ was ground in liquid nitrogen using lysis buffer and centrifuged at $16300 \mathrm{~g}$ for $10 \mathrm{~min}$. The DNA in the supernatant was extracted and estimated as described for protoplasts.

Electron microscopy. Samples for transmission electron microscopy were fixed in $2 \%(\mathrm{v} / \mathrm{v})$ glutaraldehyde in sodium phosphate buffer ( $\mathrm{pH} \mathrm{7.6)}$ containing $0.5 \mathrm{M}$-mannitol for $30 \mathrm{~min}$ followed by post-fixation in osmium tetroxide for $3 \mathrm{~h}$ at $4{ }^{\circ} \mathrm{C}$. The material was washed with $0.5 \mathrm{M}-\mathrm{NH}_{4} \mathrm{Cl}$, dehydrated in an ethanol series, and embedded in Araldite. Ultrathin sections were scanned at $80 \mathrm{kV}$ using an M 301 Philips transmission electron microscope.

Chemicals. $\beta$-Mercaptoethylamine, EDTA, RNAase T1, pancreatic RNAase and calf thymus DNA were obtained from Sigma, and glutaraldehyde, osmium tetroxide and Araldite from Polaron, Watford, UK. All other chemicals used were of Analar grade or of the highest purity available commercially.

\section{RESULTS AND DISCUSSION}

The results in Table 1 show that the yields of total protoplasts varied among the dermatophytes studied. The yield from $M$. canis HM-382 was twice that from $T$. mentagrophytes HM-325. Even isolates belonging to the same species ( $M$. canis, $T$. mentagrophytes and $T$. rubrum) differed markedly in their susceptibility to Novozym digestion. Microscopic observation revealed that $90-95 \%$ of mycelia of $M$. canis HM-382 were converted into protoplasts in $6 \mathrm{~h}$ (Fig. 1); an additional 4-5 h incubation was necessary to maximize vacuolation and hence recovery. These protoplasts lysed on dilution and showed varying degrees of susceptibility to cationic, anionic and non-ionic detergents (data not shown), thus resembling plant protoplasts (Ruesnik, 1971).

Ultrathin sections of these protoplasts (Fig. $2 a$ ) revealed that their cell membrane was totally naked with no remnants of mycelial cell wall (Fig. $2 b$ ). The vacuoles responsible for flotation were clearly discernible. At the stage of release, the protoplasts were $2.5-4.0 \mu \mathrm{m}$ in diameter but they increased in size two- to threefold, depending on the degree of vacuolation. The increased size may have been due to selective uptake of water resulting in membrane stretching (Marquis \& Corner, 1976).

The yields of DNA from both mycelia and protoplasts of $M$. canis and $M$. gypseum were compared. When expressed per gram equivalent of mycelium, the direct method yielded $62.4 \mu \mathrm{g}$ DNA from mycelia as compared with $96.7 \mu \mathrm{g}$ DNA from protoplasts. The corresponding DNA yields from $M$. gypseum were $60.8 \mu \mathrm{g}$ (mycelia) and $102.5 \mu \mathrm{g}$ (protoplasts). The recovery of DNA from mycelium through protoplast formation was $55-69 \%$ higher compared with that from

Table 1. Efficiency of Novozym 234 in effecting protoplast formation from dermatophytes

Each $\mathrm{ml}$ of incubation mixture contained $100 \mathrm{mg}$ (fresh weight) mycelium. The results are averages of four independent experiments.

\begin{tabular}{llc}
\multicolumn{1}{c}{ Organism } & Isolate & $\begin{array}{c}10^{-6} \times \text { No. of } \\
\text { protoplasts } \mathrm{ml}^{-1}\end{array}$ \\
Microsporum canis & HM-382 & 8.9 \\
& UK & $6 \cdot 1$ \\
Microsporum gypseum & & $5 \cdot 4$ \\
Trichophyton mentagrophytes & HM-289 & $5 \cdot 1$ \\
& HM-325 & $3 \cdot 9$ \\
Trichophyton rubrum & HM-24 & $4 \cdot 6$ \\
& HM-352 & $5 \cdot 5$ \\
Trichophyton violaceum & HM-164 & $5 \cdot 7$ \\
Epidermophyton floccosum & HM-308a & $6 \cdot 0$
\end{tabular}




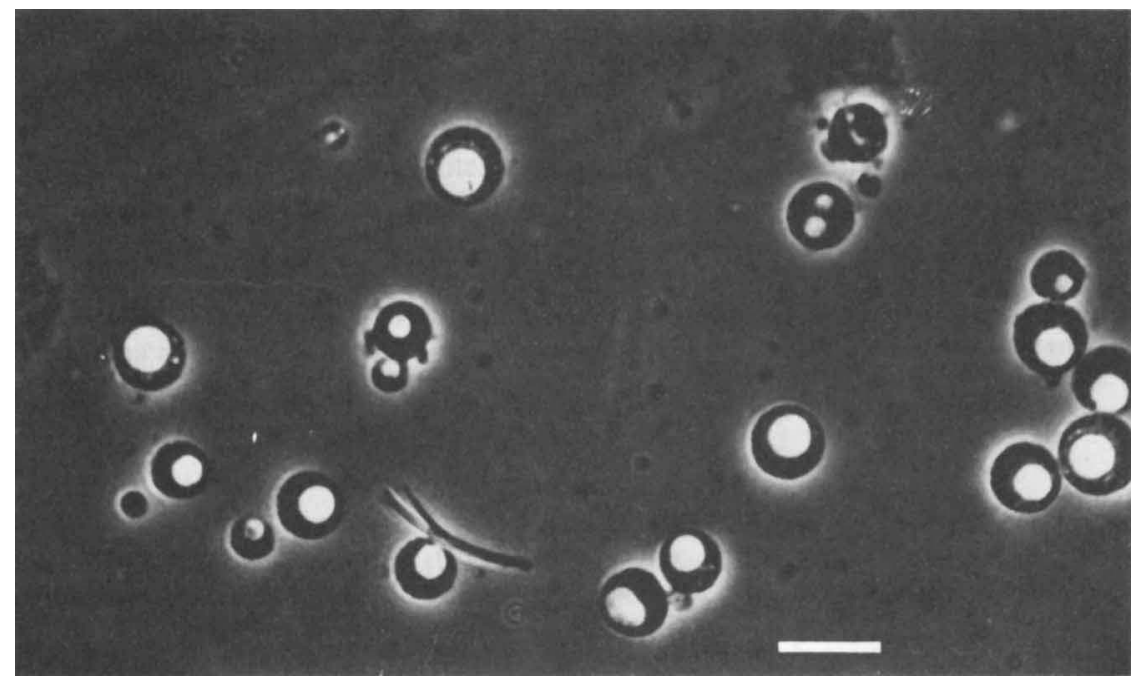

Fig. 1. Phase-contrast micrograph of protoplasts of $M$. canis. The bar marker represents $10 \mu \mathrm{m}$.
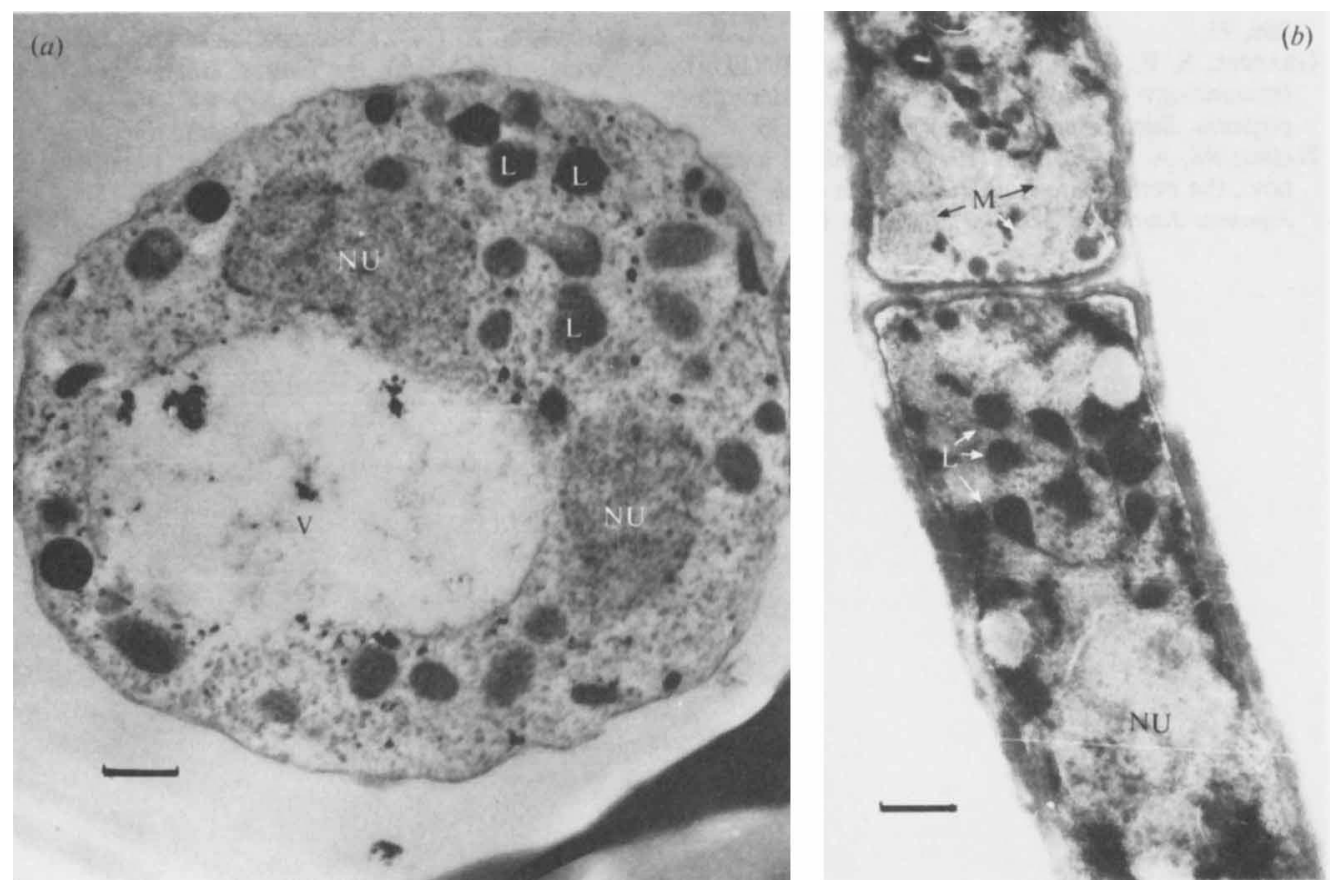

Fig. 2. Electron micrograph of $(a)$ a protoplast from $M$. canis and (b) a mycelium from $M$. canis. V, vacuole; L, lipid granules; NU, nucleus; M, mitochondria. The bar markers represent $0.5 \mu \mathrm{m}$.

direct isolation from mycelia. Protoplasts have been successfully used as a starting material to obtain both higher yields and high molecular weight DNA from Aspergillus nidulans (Morris, 1978). Since floating protoplasts represent only $65-70 \%$ of the total protoplast population, the yields of DNA or chromatin would be $130 \mu \mathrm{g}$ DNA per g mycelium, when calculated for the total protoplast population. The method described here is likely to aid isolation, purification and 
fractionation of individual chromosomes from fungi, as it is now possible from animal systems (Davies et al., 1981).

Although dermatophytes have been extensively studied with respect to pathological and immunological aspects (Grappel et al., 1974), not much is known of the molecular aspects of these important human pathogens. The protoplast system developed in the present study should serve as a useful tool in the isolation of intact organelles, in somatic fusion and in genetic transformation.

We are indebted to Novo Industri, Denmark for the generous gift of Novozym 234 and to Dr Ram Mohan of the National Institute of Mental Health and Neuro Sciences, Bangalore for his valuable help and advice in ultrastructural studies.

\section{REFERENCES}

Davies, K. E., Young, B. D., Ellis, M. E. \& Williamson, R. E. (1981). Isolation of X-chromosomes from human cells. Nature, London 293, 374376.

Dill, B. C. \& STOCK, J. J. (1974). A method for the isolation of nuclei from the dermatophytic fungus, Microsporum gypseum. Archives of Microbiology 96, 281-289.

Giles, A. W. \& MYERS, A. (1965). An improved method for the estimation of DNA. Nature, London 206, 93.

Grappel, S. F., Bishop, C. T. \& Blank, F. (1974). Immunology of dermatophytes and dermatophytosis. Bacteriological Reviews 38, 222-250.

Hasegawa, A. \& Usul, K. (1975). Nannizzia otea sp. nov., the perfect stage of Microsporum canis Bodin. Japanese Journal of Medical Mycology 16, 148-153.
Leighton, T. J., Dill, B. C., Stock, J. J. \& Phillips, C. (1971). Absence of histones from the chromosome proteins of fungi. Proceedings of the National Academy of Sciences of the United States of America 68, $677-680$.

MARquis, R. E. \& CORNER, T. R. (1976). Isolation and properties of bacterial protoplasts. In Microbial and Plant Protoplasts, pp. 11-13. Edited by J. F. Peberdy, A. H. Rose, H. J. Rogers \& E. C. Cocking. New York: Academic Press.

MORRIS, N. R. (1978). Preparation of large molecular weight DNA from the fungus Aspergillus nidulans. Journal of General Microbiology 106, 387-389.

RUESNIK, A. W. (1971). The plasma membrane of Avena coleoptile protoplasts. Plant Physiology 47, 192-195. 